\title{
REFORMULASI BAHASA SANTUN SEBAGAI UPAYA MELAWAN KEKERASAN VERBAL TERHADAP ANAK
}

\author{
Achmad Zuhrudin \\ Universitas Islam Negeri (UIN) Walisongo Semarang \\ e-mail: zuhrudinws@yahoo.co.id
}

\begin{abstract}
Abstrak
Verbal abuse for child is often unrealized by teachers at school and parents at home. It is worrying because it brings negative impact until he grows into adulthood. As a result, the spoken words may affect his emotional condition. Generally, verbal abuse is committed by adults to child for the sake of expressing caring and affection. However, it is actually forbidden for parents and teachers to control their child's behavior by committing violence. They might give punishment to their children by abandoning his right to do what he likes, while parents could reward their children when he does goodness. Indeed, parents and teachers should not give punishment or scold their child in front of his friends because it can break his self-esteem. Before scolding or punishing a child, parents or teachers should try to find out the reason why the child commits bad behavior.
\end{abstract}

Kekerasan verbal terhadap anak sering tidak disadari oleh guru di sekolah dan orang tua di rumah. Hal ini sangat mengkhawatirkan karena membawa dampak negative sampai anak tumbuh menjadi dewasa. Akibatnya, ucapan atau kalimat yang dilontarkan tersebut dapat mempengaruhi kondisi emosional anak. Umumnya, kekerasan verbal dilakukan oleh orang dewasa kepada anak, alasannya sebagai ungkapan kepedulian dan tanda kasih sayang. Akan tetapi tidak diperbolehkan bagi orang tua dan guru mengatur perilaku anak dengan kekerasan. Jika melalui wejangan tidak efektif, guru atau orang tua bisa memberikan hukuman misalnya dicabut haknya dalam melakukan hal yang disukainya, dan memberikan hadiah ketika anak melakukan hal-hal yang baik. Orang tua maupun guru sebaiknya tidak memberikan hukuman ataupun memarahi anak terutama di hadapan teman-temannya karena bisa menjatuhkan harga diri anak. Sebelum memarahi atau menghukum anak sebaiknya coba mencari tahu alasan anak mengapa melakukan tindakan tersebut.

Kata Kunci: kekerasan; bahasa; santun 


\section{A. Pendahuluan}

Dalam kehidupan sehari-hari, manusia menggunakan bahasa untuk berinteraksi satu sama lain, sebab bahasa merupakan alat komunikasi manusia. Sesuai dengan fungsinya, bahasa memiliki peran sebagai penyampai pesan antara manusia satu dengan lainnya. Dalam berbahasa, manusia perlu memperhatikan adanya kesantunan dalam mengeluarkan kata-kata. Hal itu bertujuan agar manusia penerima merasa dihargai dan mendengarkan dengan nyaman. Sebuah tuturan dikatakan santun atau tidak, sangat tergantung pada ukuran kesantunan masyarakat penutur bahasa yang dipakai.

Dalam mendidik anak, bahasa merupakan poin utama yang harus diperhatikan bagi guru. Namun, tanpa disadari penggunaan bahasa dalam pendidikan bisa mengandung kekerasan yang sangat berdampak pada anak. Guru di sekolah dengan sadar atau tidak, mungkin sering melakukan kekerasan verbal pada anak. Padahal dampak yang ditimbulkan dari kekerasan verbal ini sangat berpengaruh terhadap mental dan tumbuh kembang anak.

Ketika dampak-dampak tersebut tidak terdeteksi oleh guru dan tidak ditangani dengan tepat, maka kemungkinan dampak-dampak tersebut akan terbawa hingga dewasa. Kekerasan verbal pada anak juga akan menyebabkan anak kehilangan harga diri dan rasa percaya diri. Di antara penyebab guru sering melakukan kekerasan verbal kepada anak adalah kurangnya pengetahuan mereka dalam mendisiplinkan anak. ${ }^{1}$

Dalam mendidik anak yang belum banyak memiliki pengalaman, guru maupun orang tua harus memberikan pendidikan verbal yang ramah dan santun. Hal ini dikarenakan perlakuan dan pola komunikasi yang didapatkan anak akan sangat berpengaruh pada pembentukan karakter dan mental anak. Pada dasarnya anak usia dini belajar dari apa yang ia lihat. Sehingga anak adalah pembelajar yang cepat dan peniru yang ulung.

Berbahasa dalam mendidik anak menjadi sangat penting digunakan dalam proses dan hasil. Dalam proses komunikasi terhadap anak, bahasa menjadi sangat penting. Sebuah bahasa akan dianggap penting jika memenuhi tiga

'Soetjiningsih, "Masalah Perlindungan Anak \& Tumbuh Kembang Anak", makalah, EGC, Jakarta, 1995, h. 5. 
kriteria: jumlah penutur, luas daerah penyebaran bahasa dan terpakainya bahasa dalam sarana ilmu. ${ }^{2}$ Jadi bahasa sebagai alat komunikasi ilmu sangat dekat dengan tiga ranah sosial, yakni pendidikan. Ada beberapa karakter bahasa yang dipergunakan dalam proses pendidikan yang meliputi bahasa dalam kelas (organized class instruction) dan bahasa di luar kelas (out class organized). Keduaduanya membutuhkan model bahasa yang baku dan sesuai dengan kondisi budaya yang ada.

Di antara budaya Timur yang selalu dekat dengan norma sosial bangsa Indonesia adalah feodalistik, artistik dan moralistik. Pelaksanaan pendidikan juga tidak jauh dari ketiga norma sosial tersebut, sehingga dibutuhkan satu model pendidikan bahasa santun. Dimana pendidikan bahasa santun ini menjadi konsep pendidikan yang berkarakter memperteguh nasionalisme dan menjunjung tinggi moralitas bangsa. Jika pendidikan disampaikan dengan kesantunan berbahasa, maka peserta didik juga akan meniru bahasa santun yang didapatkan dalam pendidikan. Ini merupakan cerminan dari efek perilaku manusia. Kalau perilaku mencakup segenap pernyataan hidup organisme, maka butuh banyak deskripsi.

Kesantunan berbahasa dalam perspektif Islam merupakan dorongan ajaran untuk mewujudkan sosok manusia agar memiliki kepribadian muslim yang utuh (kaffah), yakni manusia yang memiliki perilaku yang baik dalam pandangan manusia dan sekaligus dalam pandangan Allah. Al-Quran sendiri diturunkan kepada manusia karena memiliki sifat sebagai makhluk yang memerlukan komunikasi. Oleh karena itu, al-Quran memberikan tuntunan berkomunikasi, khususnya berbahasa bagi manusia. Dalam hal berkomunikasi, ajaran Islam memberi penekanan pada nilai sosial, religius, dan budaya. sebagaimana diisyaratkan dalam ayat berikut:

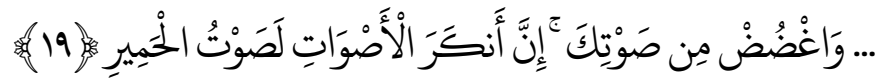

"... dan lunakkanlah suaramu, sesungguhnya seburuk-buruk suara adalah suara himar.” (QS. Lukman [31]: 19)

2Zainal Arifin \& S Arman Tasai, Cermat Berbahasa Indonesia, Jakarta: Akademika Pressindo, 2003, hal.13

${ }^{3}$ al-Qur'an al-Karim 
Maka dari itu, penulis mencoba membangun paradigma pendidikan berbahasa santun dalam lingkungan sekolah. Dalam penulisan ini diharapkan akan munculnya kebudayaan dan prilaku yang memberikan ajaran dalam berbahasa yang ramah terhadap anak.

\section{B. Pengertian Kekerasan Verbal}

Kekerasan merupakan perlakuan seseorang terhadap orang lain yang menimbulkan ketidaknyamanan baik secara fisik maupun psikis. Sementara kekerasan anak adalah perlakuan orang dewasa atau anak yang lebih tua dengan menggunakan kekuasaan atau otoritasnya terhadap anak yang tak berdaya yang seharusnya menjadi tanggung jawab dari orang tua atau pengasuh yang berakibat penderitaan, kesengsaraan, cacat atau kematian. ${ }^{4}$ Penganiayaan fisik adalah tindakan kasar yang mencelakakan anak dan segala bentuk kekerasan fisik pada anak yang lainnya. Sedangkan penganiayaan psikis adalah semua tindakan merendahkan atau meremehkan anak. Kekerasan psikis dalam kalimat lain disebut kekerasan verbal.

kekerasan verbal merupakan perlakuan yang biasa dari orang tua. Perlakuan yang salah pada anak adalah akibat dari tumbuh kembang anak yang tidak diketahui oleh orang dewasa, baik secara fisik, psikologi sosial maupun mental. Bentuk kekerasan seperti ini sering diabaikan dan dianggap biasa atau bahkan dianggap sebagai candaan. Kekerasan seperti ini biasanya meliputi hinaan, makian, maupun celaan. Dampak dari kekerasan seperti ini yaitu anak jadi belajar untuk mengucapkan kata-kata kasar, tidak menghormati orang lain dan juga bisa menyebabkan anak menjadi rendah diri.

Contoh kekerasan verbal yang sering dilakukan terhadap anak adalah sebagai berikut: ${ }^{5}$ ) Tindakan intimidasi, seperti; berteriak, menjerit, mengancam, menggeretak anak. 2) Tindakan mengecilkan atau mempermalukan anak, seperti; merendahkan anak, mencela nama, membuat perbedaan negatif antar anak, mengatakan bahwa anak "tidak baik, tidak berharga, jelek atau sesuatu yang didapat dari kesalahan". 3) Tidak sayang dan dingin, seperti; menunjukkan

\footnotetext{
h. 6 .

${ }^{4}$ Sutanto, Psikologi Perkembangan Anak dan Remaja, (Jakarta: BPK Gunung Mulia), 2006),

${ }^{5}$ Dumas, Jean E. \& Wendy J. Nilsen. Abnormal Child and Adolescent Psychology, (Boston: Pearson Education Inc, 2003), h. 34.
} 
sedikit atau sama sekali tidak rasa sayang kepada anak (seperti pelukan) atau kata-kata sayang (pujian, kata "aku sayang kamu", dll). 4) Kebiasaan mencela anak, seperti; mengatakan bahwa semua yang terjadi adalah kesalahan anak. 5) Tidak mengindahkan atau menolak anak, seperti; tidak memperhatikan anak, memberi respon yang dingin, tidak peduli dengan anak. 6) Hukuman ekstrim, seperti; mengurung anak dalam kamar mandi atau kamar gelap, mengikat anak di kursi untuk waktu yang lama atau meneror anak (menakuti anak). 7) Mengekspos kekerasan, seperti; menunjukkan tindakan kekerasan pada anak, termasuk di dalamnya kekerasan fisik yang dilakukan orang lain. 8) Mengekploitasi anak, seperti; memanfaatkan anak untuk tujuan tertentu, termasuk didalamnya memperkerjakan anak dibawah umur. 9) Penculikan anak, seperti: trauma dari membawa lari anak, termasuk didalamnya penculikan yang dilakukan oleh orang tua sendiri, dan beberapa kekerasan lainnya.

\section{Faktor Terjadinya Kekerasan}

Kekerasan verbal biasanya dilakukan oleh orang yang terdekat dengan anak. Baik orang tua, guru dan bahkan pengasuh. Secara umum, tindakan kekerasan verbal tersebut dapat diartikan sebagai suatu tindakan yang dapat merugikan orang lain secara psikis. Banyak dari mereka, yang tidak menyadari dengan melakukan kekerasan fisik. Sebab tidak bisa dilihat dampaknya oleh mata, justru karena tidak terlihat oleh mata kekerasan psikislah yang perlu diwaspadai karena akan menimbulkan efek traumatis yang cukup lama bagi si korban. Kekerasan verbal pada anak menurut hasil survei KPAI tahun 2013 pemicu terjadinya adalah di antaranya yaitu: 1) Kekerasan dalam rumah tangga, yaitu terjadinya kekerasan yang melibatkan baik pihak ayah, ibu dan saudara yang lainnya. 2) Disfungsi keluarga, yaitu peran orang tua tidak berjalan sebagaimana seharusnya. Adanya disfungsi peran ayah sebagai pemimpin keluarga dan peran ibu sebagai sosok yang membimbing dan menyayangi, 3) Faktor ekonomi, yaitu kekerasan timbul karena tekanan ekonomi. Tertekannya kondisi keluarga yang disebabkan himpitan ekonomi adalah faktor yang banyak terjadi, 4) Pandangan keliru tentang posisi anak dalam keluarga. Orang tua menganggap bahwa anak adalah seseorang yang tidak tahu apa-apa. Dengan demikian pola asuh apapun berhak dilakukan oleh orang tua.

Namun kesemua pemicu tadi yang paling dominan adalah faktor penyebab terinspirasinya dari tayangan-tayangan televisi atau internet dan media-media lainnya yang tersebar di lingkungan masyarakat. 
Fenomena ini akhirnya menjadi suatu mata rantai yang tidak terputus, di mana setiap generasi akan memperlakukan hal yang sama untuk merespons kondisi situasional yang menekannya. Adapun penyebab guru dan orang tua melakukan kekerasan kata-kata (verbal abuse) dikarenakan kurangnya pengetahuan orang tua. Orang tua yang tidak mengetahui atau mengenal sedikit informasi mengenai kebutuhan perkembangan anak, misalnya harapan-harapan orang tua yang tidak realistik terhadap perilaku anak berperan memperbesar tindakan kekerasan pada anak.

\section{Dampak Kekerasan terhadap Anak}

Ada beberapa dampak dari kekerasan verbal pada anak, Ketika dampakdampak tersebut tidak terdeteksi oleh orang tua dan tidak ditangani dengan tepat, maka kemungkinan yang terjadi adalah dampak-dampak tersebut akan berpengaruh hingga dewasa. Sehingga proses perkembangannya si anak akan terus terganggu. Berikut beberapa dampak yang mungkin terjadi yaitu berupa: ${ }^{6}$ ) Hilangnya kepercayaan diri pada anak. Karena sering disalahkan dan dimarahi, anak akan kehilangan rasa percaya dirinya. 2) Muncul perasaan tidak berdaya pada anak. Ketika anak disalahkan, anak merasa tidak mampu dalam hal apapun dan membuat anak mudah menyerah. 3) Prestasi yang terus menurun, baik prestasi di sekolah maupun luar sekolah. Karena jarang dipuji, anak tidak semangat dalam hal apapun termasuk bidang akademik. 4) Lemahnya daya kreativitas anak. Karena merasa apa yang dilakukan salah, anak enggan melakukan hal baru. Anak hanya akan menerima dan menunggu hal baru. 5) Muncul kecemasan dalam diri anak. Anak yang sering dibandingkan dengan anak lain, sering dimarahi dan sering mendapat teguran yang salah akan merasa cemas dan was-was berlebih. 6) Anak kesulitan berhubungan dengan teman sebaya karena hilang kepercayaan dirinya. Karena hilangnya rasa percaya diri anak, anak mulai mengunci dirinya dari lingkungan sekitar. Anak merasa rendah diri dan malu untuk bersosialisasi. 7) Murung/Depresi. Kekerasan verbal mampu membuat anak berubah drastis seperti menjadi anak yang memiliki gangguan tidur dan makan, bahkan bisa disertai penurunan berat badan. Ia akan menjadi anak yang pemurung, pendiam, kurang percaya diri dan terlihat kurang

${ }^{6}$ Singgih D. Gunarsa Yulia Singgih D. Gunarsa, Psikologi Praktis: Anak, Remaja dan Keluarga (Jakarta: BPK Gunung Mulia, 1993), h. 25. 
ekspresif. 8) Mudah menangis. Sikap ini ditunjukkan karena anak merasa tidak nyaman dan aman dengan lingkungan sekitarnya. Karena dia kehilangan figur yang bisa melindunginya, kemungkinan besar pada saat dia besar, dia tidak akan mudah percaya pada orang lain.9) Seorang anak pada hakikatnya akan lebih bersemangat ketika mendapat reward. Hindari kata-kata yang bersifat mengancam atau menakuti anak, Kekerasan juga tidak selamanya akan membuat anak berhasil, hal ini hanya akan membuat anak yang patuh ketika di awasi saja dan melakukan yang sebaliknya ketika di luar pengawasan.?

\section{Bahasa Santun}

\section{Konsep Bahasa Santun}

Dalam buku Berbahasa Secara Santun karya Pranowo, ${ }^{8}$ dibahas mengenai kesantunan dalam berbahasa. Struktur bahasa yang santun adalah struktur bahasa yang disusun oleh penutur atau penulis agar tidak menyinggung perasaan pendengar atau pembaca. Bahasa yang benar adalah bahasa yang dipakai sesuai dengan kaidah yang berlaku. Seseorang sedang berkomunikasi dalam situasi tidak resmi, mereka menggunakan kaidah bahasa tidak resmi. Ketika seseorang sedang menulis karya ilmiah untuk makalah, skripsi, tesis, atau disertasi mereka menggunakan kaidah bahasa baku. Jika penulis sedang memerankan tokoh pejabat, maka bahasa yang digunakan adalah kaidah bahasa resmi.

Masih ada satu kaidah lagi yang perlu diperhatikan yaitu kesantunan. Ketika seseorang sedang berkomunikasi, hendaknya disampaikan baik dan benar juga santun. Kaidah kesantunan dipakai dalam setiap tindak bahasa. Agar pemakaian bahasa terasa semakin santun, penutur dapat berbahasa menggunakan bentuk-bentuk tertentu yang dapat dirasa sebagai bahasa santun, seperti: ${ }^{9}$ a) Menggunakan tuturan tidak langsung biasanya terasa lebih santun jika dibandingkan dengan tuturan yang diungkapkan secara langsung, b) Pemakaian bahasa dengan kata-kata kias terasa lebih santun dibandingkan dengan pemakaian bahasa dengan kata-kata lugas, c) Ungkapan memakai gaya bahasa penghalus terasa lebih santun dibandingkan dengan ungkapan biasa, d) Tuturan

${ }^{7}$ Tri Budiardjo, Anak-anak: Generasi Terpinggirkan? (Yogyakarta: ANDI, 2010), h. 21.

${ }^{8}$ Pranowo, Berbahasa Secara Santun, (Yogyakarta: Pustaka Pelajar 2009), h. 8

${ }^{9}$ Sutanto, Psikologi Perkembangan Anak dan Remaja, h. 12. 
yang dikatakan berbeda dengan yang dimaksud biasanya tuturan lebih santun, e) Tuturan yang dikatakan secara implisit biasanya lebih santun dibandingkan dengan tuturan yang dikatakan secara eksplisit.

Terlepas dari tuturan santun dan tidak santun, keduanya adalah tindakan komunikasi. Dalam setiap tindakan komunikasi dapat gagal dan dapat berhasil mencapai tujuan.

\section{Alasan Berbahasa Santun}

Bahasa merupakan alat komunikasi, berkomunikasi dengan anak merupakan interaksi primer dalam membantu kualitas pertumbuhan antara orang tua dan anak. Ada tiga hal penting ketika penutur berinteraksi dengan mitra tutur. Pertama, anak diharapkan dapat memahami maksud yang disampaikan. Kedua, setelah anak memahami maksud, anak akan mencari aspek tuturan yang lain. Ketiga, tuturan orang tua atau guru kadang-kadang juga disimak oleh orang lain (orang ketiga) yang sebenarnya tidak berkaitan langsung dengan komunikasi antar. ${ }^{10}$

Berbahasa dan berprilaku santun merupakan kebutuhan setiap orang, bukan sekedar kewajiban melainkan upaya edukasi terhadap anak. Seseorang berbahasa dan berprilaku santun sebenarnya lebih dimaksudkan sebagai wujud aktualisasi diri serta memberikan contoh terhadap anak. Setiap orang harus menjaga kehormatan dan martabat diri sendiri. Hal ini dimaksudkan agar orang lain juga mau menghargainya, inilah hakikat berbahasa secara santun.

\section{Cara Berbahasa Santun}

Santun tidaknya dapat dilihat setidaknya dari dua hal, yaitu pilihan kata (diksi) dan gaya bahasa. Pilihan kata yang dimaksud adalah ketepatan pemakaian kata untuk mengungkapkan makna dan maksud dalam konteks tertentu sehingga menimbulkan efek tertentu pada pada mitra tutur. Setiap kata yang disampaikan kepada anak, di samping memiliki makna tertentu juga memiliki daya (kekuatan) tertentu. Kesanggupan menggunakan gaya bahasa seorang penutur dapat terlihat tingkat kesantunannya dalam berkomunikasi.

\footnotetext{
${ }^{10}$ Gordon, Thomas. Mengajar Anak Berdisiplin Diri di Rumah dan di Sekolah, (Jakarta: Gramedia Pustaka Utama, 1996), h. 14.
} 
Menurut Pranowo ${ }^{11}$ bahwa agar komunikasi dapat terasa santun, tuturan ditandai dengan hal-hal berikut: a) Perhatikan suasana perasaan mitra tutur (angon rasa), b) Pertemukan perasaan Anda dengan perasaan mitra tutur (angon rasa), c) Jagalah agar tuturan dapat diterima oleh mitra tutur (empan papan), d) Jagalah agar tuturan memperlihatkan rasa ketidakmampuan penutur di hadapan mitra tutur (sifat rendah hati), 5) Jagalah agar tuturan memperlihatkan mitra tutur diposisi lebih tinggi sikap hormat), dan 6) Jagalah agar tuturan selalu memperhatikan apa yang dikatakan kepada mitra tutur juga dirasakan oleh penutur (sikap tepa selira).

Secara teoritis, semua orang harus berbahasa secara santun. Setiap orang wajib menjaga etika dalam berkomunikasi agar maksud dan tujuan komunikasi dapat tercapai dan saat menggunakan bahasa juga harus memerhatikan kaidahkaidah berbahasa baik kaidah linguistik maupun non linguistik. Adapun cara menyampaikan maksud agar tuturan dapat dikatakan santun dapat dijelaskan sebagai berikut. (1) rasa nrima (menerima keadaan seperti adanya), (2) sikap ngalah demi rasa solidaritas, (3) sikap ngalah demi rasa hormat, (4) sikap tenggang rasa, (5) sikap empan papan (menyesuaikan diri dengan waktu dan tempat). ${ }^{12}$

\section{Formulasi Bahasa Santun terhadap Anak}

Sebaiknya dalam mendidik, baik guru dan orang tua saling bekerja sama dalam menumbuhkan kepercayaan diri sang anak. Pada dasarnya hukuman menakuti anak hanya akan membentuk anak yang kurang percaya diri dan mudah menyerah. Kekerasan juga tidak selamanya akan membuat anak berhasil, hal ini hanya akan membuat anak yang patuh ketika di awasi saja dan melakukan yang sebaliknya ketika di luar pengawasan.

Orang tua secara langsung tidak menyadari bahwa mereka melakukan kekerasan kata-kata (verbal abuse). Orang tua perlu memahami anak dan tumbuh kembangnya agar dapat memberikan reward dan hukuman sesuai dengan perkembangan kemampuan anak. Serta sebisa mungkin menghindari kekerasan dalam bentuk apapun termasuk kekerasan kata-kata dan mampu mendidik anak

\footnotetext{
${ }^{11}$ Pranowo, Berbahasa Secara Santun, h. 67.

${ }^{12}$ Paulus Hadisuprapto, Masalah Perlindungan Hukum Bagi Anak, Jakarta: Gramedia Indonesia, 2007), h. 23.
} 
menjadi anak yang penurut tanpa menggunakan kekerasan dalam bentuk apapun..$^{13}$

Agar anak terhindar dari bentuk kekerasan seperti di atas perlu adanya formulasi hubungan orang tua terhadap anak, dan perlu diadakannya langkahlangkah sebagai berikut:14 a) Jangan sering mengabaikan anak, karena sebagian dari terjadinya kekerasan terhadap anak adalah kurangnya perhatian terhadap anak, b) Tanamkan sejak dini pendidikan agama pada anak. Agama mengajarkan moral pada anak agar berbuat baik, hal ini dimaksudkan agar anak tersebut tidak menjadi pelaku kekerasn itu sendiri. c) Sesekali ajaklah berbicara dengan tutur kata yang lembut, ramah, dan bicaralah secara terbuka pada anak serta berikan dorongan pada anak agar bicara apa adanya/berterus terang. Hal ini dimaksudkan agar orang tua bisa mengenal anaknya dengan baik dan memberikan nasihat apa yang perlu dilakukan terhadp anak, karena banyak sekali kekerasan pada anak terutama pelecehan seksual yang terlambat diungkap. d) Ajarkan kepada anak untuk bersikap arif, bijaksana dan santun dalam berbahasa baik kepada orang tua, sebaya maupun di bawahnya dan selalu waspada seperti jangan terima ajakan orang yang kurang dikenal. 5) Sebaiknya orang tua juga bersikap sabar terhadap anak. Ingatlah bahwa seorang anak tetaplah seorang anak yang masih perlu banyak belajar tentang kehidupan dan karena kurangnya kesabaran orang tua banyak kasus orang tua yang menjadi pelaku kekerasan terhadap anaknya sendiri.

\section{Kesimpulan}

Dari penjelasan di atas, pemakaian bahasa dapat dikatakan santun jika ada prinsip "rukun" dan "hormat". Kedua prinsip itu, adalah prinsip kerukunan dan prinsip kurmat Yang pertama mengacu pada kewajiban setiap anggota untuk menjaga kesimbangan sosial dan yang kedua, yang bermakna 'hormat', merujuk pada "kewajiban" setiap anggota masyarakat untuk menunjukkan rasa menghargai orang lain sesuai dengan status dan kedudukan masing-masing di dalam masyarakat.

\footnotetext{
${ }^{13}$ Maulana Hassan, Pengantar Advokasi dan Hukum Perlindungan Anak, (Jakarta:. Gramedia Indonesia, Jakarta 2000), h. 17.

${ }^{14}$ Gordon, Thomas. Mengajar Anak Berdisiplin Diri di Rumah dan di Sekolah, h. 34.
} 
Hematnya, bahasa membentuk perilaku manusia sejak kecil. Jika kebiasaan yang tertanama pada diri seseorang buruk, perilaku yang tumbuh dan berkembang kelak juga akan buruk. Sebaliknya, jika kebiasaan berbahasa yang tertanam pada diri seseorang adalah kebiasaan berbahasa yang baik dan ramah, perilaku bahasanya pun juga akan tumbuh buruk. Inilah pengaruh bahasa dalam membentuk budaya santun terhadap perilaku manusia.]

\section{Daftar Pustaka}

Budiardjo, Tri. Anak-anak: Generasi Terpinggirkan?. Yogyakarta: ANDI, 2010.

Dumas, Jean E. \& Wendy J. Nilsen. Abnormal Child and Adolescent Psychology. Boston: Pearson Education Inc, 2003.

Gordon, Thomas. Mengajar Anak Berdisiplin Diri di Rumah dan di Sekolah. Jakarta: Gramedia Pustaka Utama, 1996

Gunarsa D, Singgih . dan Yulia Singgih D. Gunarsa. Psikologi Praktis: Anak, Remaja dan Keluarga (Jakarta: BPK Gunung Mulia, 1993

Hadisuprapto, Paulus, Masalah Perlindungan Hukum bagi Anak, Jakarta: Gramedia Indonesia, 1996.

Hassan, Maulana, Pengantar Advokasi dan Hukum Perlindungan Anak, Jakarta: PT. Gramedia Indonesia, 2000.

http://www.kompasiana.com/faieza/kekerasan-verbal-dan-dampaknyaterhadap-mental-anak-usia-dini_566fa851529773ab0f4241dc Diakses pada tanggal 20 Januari 2016 pukul 20.47.

http://shellyicecreamvanilla.blogspot.com/2011/10/berbahasa-santun.html Diakses pada tanggal 20 Januari 2016 pukul 20.47.

Soetjiningsih, "Masalah Perlindungan Anak \& Tumbuh Kembang Anak", Makalah, EGC, Jakarta,1995.

Sutanto, Psikologi Perkembangan Anak dan Remaja. Jakarta: BPK Gunung Mulia, 2011.

Pranowo, Berbahasa Secara Santun, Yogyakarta: Pustaka Pelajar 2009

Zainal Arifin \& S Arman Tasai, Cermat Berbahasa Indonesia, Jakarta: Akademika Pressindo, 2003. 
